\title{
仙台藩への四天王寺流の伝播と継承について A STUDY ON THE SHITENNOU-JI SCHOOL IN SENDAI-HAN
}

\author{
永井康雄 ${ }^{*}$ 飯 淵 康一** \\ Yasuo NAGAI and Kouichi IIBUCHI
}

\begin{abstract}
The aim of this study is to examine the reality and the way of succession of SHITENNOU-JI school in SENDAI-HAN. HOZAWA family was the master carpenter in SENDAI-HAN. HOZAWA Masanao was succeeded SHITENNOU- $\pi$ school by FUKAYA Harunao that was a pupil of HEINOUCHI Masaharu in the Houreki period (1751-1764). HOZAWA Naoyoshi, next successor, had edited many architectual manual books and had been active as a successor of SHITENNOU-JI school. HOZAWAS established the school family in SENDAI-HAN. This school family was composed of pupils called MON-JIN (門人) that come from variety range of social standings. On the other hand, the pupils called KEIKO-NIN (眇古人) had been in SENDAI-HAN. KEIKO-NIN was selected from among young carpenters by SENDAI-HAN. The succession of SHITENNOU-JI school was very strict.
\end{abstract}

Reywords : SHITENNOU-JI School, SENDAI-HAN, carpenter, Edo period 四天王寺流，仙台藩，大工，江戸時代

\section{序}

江戸時代の建築界に幕府の大棟梁職にあった平内・甲良両家をそ れぞれ宗家とする四天王寺・建仁寺の二大流派が存在していたのは 周知の通りである。そしてこれら両流派が諸藩の大工へと伝播して いつた事実が存在することもよく知られるところである ${ }^{1) 。 し か し ~}$ ながら、両流派の成立過程でさえも必ずしも十分に明らかにされて いるわけではなく、各々の流派の技術等が諸藩の大工へと伝播して いつた過程、そして諸藩の大工にとって流派を継承することの社会 的意義、さらには流派の技術等の伝播が諸藩の建築技術に及ぼした 影響等々を解明することは、我国の近世建築文化を理解する上で重 要な課題と言えよう2)。

仙台藩の大工棟梁職を勤めた朴澤家は、後述のように幕府大棟梁 平内政治の門弟であった深谷平左衛門治直より宝暦年中 (1751-1764) に四天王寺流の皆伝を受け、その後明治に至るまで同流を継承する 同藩の代表的な工匠家として存続した。この朴澤家に伝来した古文 書類や絵図面類、木割書を始めとする建築技術書類の多くは「朴沢 家資料」として仙台市博物館に遺されている。本稿は上述の諸問題 を解明するための端緒として、これらの史料を基に、これまで殆ど 知られていなかった仙台藩への四天王寺流伝播の経緯とその後の藩 内での同流継承の在り方などを明らかにしようとするものである。

\section{1. 朴潀家の系渞}

図- 1 は朴澤家九代目左蔵が大正 12 年 (1923) に宮城縣土木係へ提 出した「朴澤庄蔵履歴書」 ${ }^{3)}$ を基に、他の諸史料4)の内容を加えて作 成した朴澤氏の家譜である。

仙台潘御抱え工匠としての朴澤家の歷史は、宮城郡根白石在字朴 澤 (現仙台市泉区) 出身の初代甚助が寛永 2 年 (1625)に仙台藩初代藩 主伊達政宗に御大エとして五し出された時に始まる。

先ず朴澤家が勤仕した役職について見ると、初代甚助は御大工、 三代安右衛門崵所主立、四代十四郎は享保元年 (1716)に脇棟梁及 御積り職となり、享保13年 (1728) からは御大工棟梁を勤めている。 五代左蔵は明和2年 (1765) に御大工棟梁職を仰せ付けら九、寛政6年 (1794)には御大工棟梁并吟味役仮役となっている。六代孫太郎は御 積横目大工加勢、七代庄蔵は御大工絵圖方主立、八代十四郎は御大 工御積横目大工加勢を勤めている。仙台藩の職制では藩主の下に奉 行が置かれ、更にその下に若年寄や出入司などの要職が置かれてい た。「司属部分録」 ${ }^{5)}$ には、出入司支配として「御作事方 [同所御足軽] /一本メ横目御役人等/(中略)/御作事方本メ支配/御大工木挽屋根 惪/御瓦師等諸職人等/棟梁共/ (中略) 御細工番頭立/御用支配/御供 大工/御張付/右八御作事方職人/(後略)」([ ]は割注: /は改行を示す。) が記されている。つまり御作事方本メ等の役人法出入司の配下にあ
* 東北大学大学院工学研究科 講師 - 博士 (工学)

** 東北大学大学院工学研究科教授. 工博
Lecturer, Graduate School of Engineering, Tohoku Univ., Dr. Eng. Prof., Graduate School of Engineering, Tohoku Univ., Dr. Eng. 


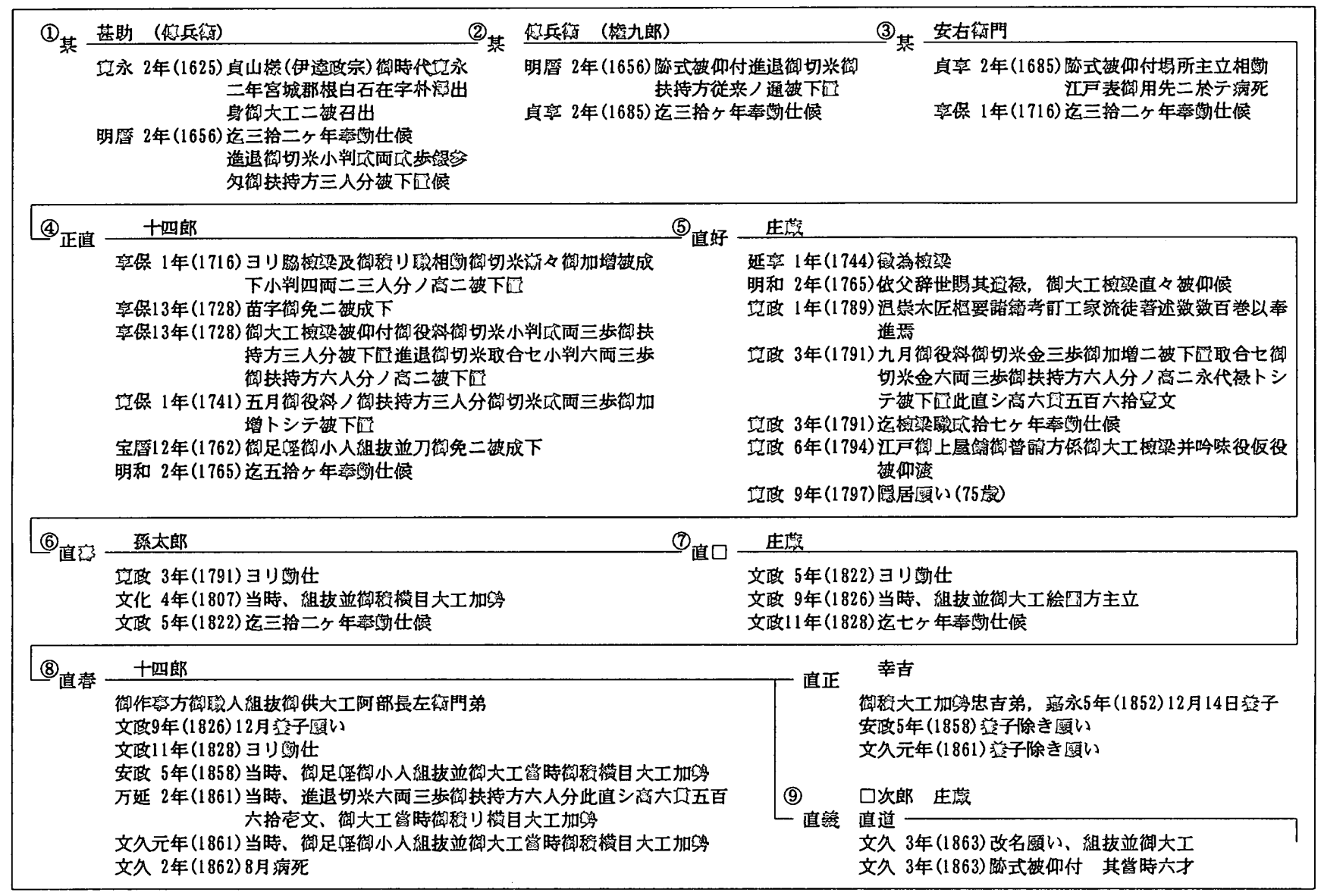

\section{図一 1 朴彎氏家渞}

り、梖梁以下の諸職人はこの御作事方本 の支配を受けるが、御供 大工御作事方の職人でありながら職務上は御細工番頭の支配を受 けるものであったことが知られる。また、仙台藩における工匠に関 する役職については、上位から御大工穂梁吟味役兼役・御大工棈梁

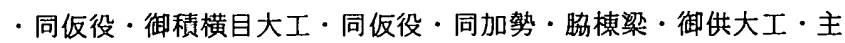
立御大工・御大工・御小屋仮大工などが存在したことが知られてい $3^{6)}$ 。

次に、朴澤家の家格などについて見てみたい。四代十四郎は享保 13年 (1728)に苗字御免となり、更に宝暦12年 (1762)には「御足軽御 小人組抜並刀御免」となっている。次の五代の時の家格を示す史料 は見い出せないが、六代から九代までは何れも「御足軽御小人組抜 並」(又は単に組抜並とも記す) ${ }^{7)}$ であることから、四代の時に許さ れた家格は永代のものであったと考えられる。仙台潘では藩士は門 閂・平士・組士などの士分と、雄本・組抜・小人・同心・足軽など 0)卒以下の者で凡下と総称される階級とに分けられ、職人組 ${ }^{8)}$ はこ の凡下の中に含まれていた ${ }^{9)}$ 。仙台藩工匠の中には朴澤家のように 【御足軽御小人組抜並」(組抜並)という家格を与えられた者と「御作 事方御職人組抜」という家格を与えられた者とが存在していた ${ }^{10)}$ 。 〔仙害府諸士版籍」 ${ }^{11}$ の「御足軽小人組以下之組御免被成下候者」の 項に朴澤家六代目・孫太郎の名が記されているので、これと同家が 許された「御足軽御小人組抜並」(組抜並)とは同一のものであること が知られる。一方、同書には「御作事方御職人組抜」に該当する項目 は見られず、「面々諸職人」という項目の中にこの肩書を有する御大 工等が記されている(2)。従って(御足軽御小人組抜並」(組抜並)と
「御作事方御職人組抜」との間には明確な身分的差異が存在していた ことが知られる。即ち、前者は諸職人階級を脱して卒身分で無役の 者である「組抜」並となったことを意味し、後者は職人組には属さな いものの未だ職人階級にあることを示していると考えられる。この ことは前出の「司属部分録」に記される支配系統が、横梁以下の諸職 人は御作事方本ð支配、「御足軽御小人組抜並」は御郡奉行支配 ${ }^{13)}$ 、 と両者相違していることからも箱うことが出来よう。

以上より、朴澤家は四代十四郎正直以降、工匠出身者の中ではか なり上位の役職・家格であったことが知られる。

\section{2. 朴湦家の四天王寺流皆伝}

朴澤家五代生蔵直好の墓碑 ${ }^{14}$ ) には少而受業於父十四郎其師深谷 平左衛門治通先師四天王寺流江府平内政治也」の記述がある(巻末の [史料 1] 参照)。また、前出の[朴澤生蔵履歴書」には朴澤家四代十 四郎の項に続いて木匠道の相伝に関する記述があり、「武州江戸四

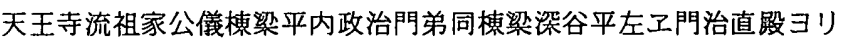

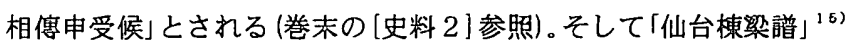
には「御大工楎梁朴沢十四郎宝暦年中公義御大工掼梁平内政治門弟 二被相登嵇古仕候処皆僡八深谷平左衛門殿 5 傳授仕候尤受領仕大隅 殿卜被成下候事夫承及之事」とある。これらを総合すると、四代目 十四郎正直が江戸幕府大棲梁平内政治の門弟である潹谷平左衛門治 直から宝曆年中 (1751-64)に四天王寺流を相伝したことが明らかと なる ${ }^{16) 。 ~}$

前述のように朴澤家が仙台藩の工匠の中で重要な役職に就くのは 


\section{表一 1 朴㵏十四郎正直が従事した造営など}

\begin{tabular}{|c|c|c|}
\hline 年 代 & 普目 揚 所 な ど & 役 方 \\
\hline 享保 4年(1719) & 肯山様 (四代潘主伊逢網村)御卒去御舞 & 御葬礼方脇棟梁 \\
\hline 卓保 5年(1720) & 江戸御上屋鋪 & 御新宅方脇楝梁 \\
\hline 享保15年(1730) & 宫末両八橎宫并末社賞照寺方丈 & 御普筲方棟梁 \\
\hline $\begin{array}{c}\text { 字保19-20年 } \\
\text { (1734-35) }\end{array}$ & 璃風殿 & 御再興方 \\
\hline 窅保元年(1741) & 宮床覚照寺方丈被相建御用 & \\
\hline 寛保 2年(1742) & 国分㳊胝堂 & 御透営方 \\
\hline $\begin{array}{r}\text { 寛保2-3年 } \\
(1742-43) \\
\end{array}$ & 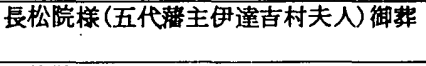 & 御卌礼方 \\
\hline 寛保 3年(1743) & 長松院样御雨屋 & 御普薂方 \\
\hline 寛保 3年(1743) & 雲松院㥞（六代藩主伊達宗村夫人）御渥 & 御葬礼方 \\
\hline 筧保 3年(1743) & 雲松院様御雨屋 & 御普請方 \\
\hline 窅延元年(1748) & 大橋御懸替御用 & \\
\hline $\begin{aligned} \text { 宝暦元-2年 } \\
\quad(1751-52)\end{aligned}$ & 東数山御手専 & $\begin{array}{l}\text { 御普百方方 } \\
\text { (御釿初御被) }\end{array}$ \\
\hline 宝曆 6年(1756) & 忠山樣(六代藩主伊達宗村)御桃 & 御葬礼方 \\
\hline 宝暦 7年(1757) & 忠山样御廟 & 御普锖方 \\
\hline 宝暦 7年(1757) & 屋形栚（七代藩主重村）御入部 & 御入部方 \\
\hline 宝暦10年(1760) & 性善院様御屋鋪御普箐 & \\
\hline
\end{tabular}

四代目十四郎正直の代からであった。この十四郎が従事した造営に

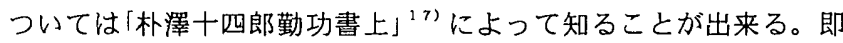
ち、正直が従事した主な造営俵一 1 に示すようなものであった。 正直が四天王寺流を相伝するの性宝暦年中であるが、それ以前から 既に脇棟梁や棟梁として数々の普請などを手掛けている。この中で 宝暦元年 (1751) から同2年 (1752)にかけて行われた東軴山御手伝普 請は、その他の主として国許で行われたものとは異なり幕府の普請 であったという点で注目される。仙台藩六代藩主伊達宗村は宝暦元 年に幕府より東澂山常憲院殿の修理と宝塔の造立を命ぜられた ${ }^{18)} 。$ 「朴澤十四郎勤功書上小には「宝暦元年一御金壱切 東跧山御手傳御

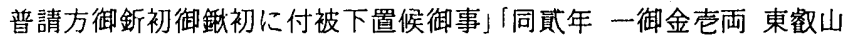
御手傳御普請方奉勤仕被下置候御夏」とのみ記されるが、十四郎正 直はこの普請に際して釿初・鈋初の儀式を担当していることから藩 を代表する工匠の一人として従事したことが知られる。このことと ほぼ時を同じくして正值が四天王寺流を相伝したこととは無緑では あるまい ${ }^{19)}$ 。周知のように江戸時代初頭の仙台藩では大崎八幡宮 ・瑞㧨寺・仙台城本丸大広間などの建築に際し、京都からは梅村氏 を呼び笴せ、また紀州からは刑部左衛門国次、泉州からは駿河守宗 次を㕍うなど ${ }^{0)}$ 、積極的に上方の建築文化・技術を取り入れてい る。上方からの建築技術の移入は元禄期 (1688-1704)に至っても行 才れており、「仙台棟梁譄」には「一宮城塩釜一ノ宮御造営之砌 ${ }^{211}$ 元録年中御大工棟梁松原助兵衛 ${ }^{22}$ 同脇棟梁八九郎卜申者京都江被 相登藤本丹波守殿江入門仕木工匠道皆傳仕罷下候事」との記述があ る。これには「被相登」とあることからも、御大工棟梁と同脇棟梁が 上洛して藤本丹波守 ${ }^{231}$ に入門したのは藩命によるものであったこ とが知られる。「仙台棟梁譄」の朴澤家四天王寺流皆伝に関する記述 にもこれと同様に「被相登」と記されることから、これも仙台潘成立 以来行われてきた中央の先進技術を積極的に移入するという方策の 一環として捉えることができ、朴澤十四郎が江戸に登ったのもやは り藩命であったと考えられる。

また一方、このことは平内家を宗家とする四天王寺流の成立時期 を考える上でも興味樑い。即ち上述のように元禄期 (1688-1704) 以 前の仙台潘では京都及びその周辺の建築技術の掑取に努めたのに対 し、宝暦年中 (1751-64)になると江戸のものをその対象としたとい う点である。四天王寺流の根本的な木割書である「匠明」が現在見ら

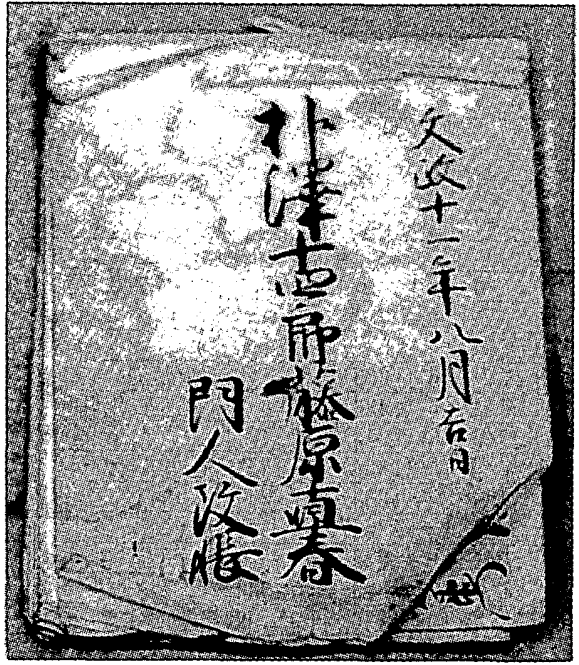

写真一 1 朴濐十四郎藏原直春門人改帳

れるような形に大成されたのが享保 (1716-36) 頃であること ${ }^{24)}$ を鑑 みると、四天王寺流は元禄期以降に確立され、遅くとも宝暦期には 当時の建築界を代表する流派として諸藩においても認められるよう になっていたと言うことになろう。このように考えると、前に述べ たように朴澤十四郎が宝暦12年 (1762)に「御足軽御小人組抜並刀御 免よとうエ匠としてかなり高い格式を与えられたのは、藩命によ つて四天王寺流を皆伝されたことがその要因の一つであったと推定 することが出来よう。

\section{3. 仙台藩における朴睪一門}

朴澤家が四天王寺流を皆伝された後、仙台藩内で一門を形成して いたことを示すものの一つに文政十一年八月吉日/朴澤十四郎藤原 直春/門人改帳」 ${ }^{26)}$ (以下[門人改帳」之略称する。写真-1) と題する 史料がある。これには59人の氏名、年月日、職名及び血緑関係、地 名などが記されている。表- 2 は、これらを氏名の記載順に整理し たものである。

先ず、当史料の表紙に記される「文政十一年八月吉日」の意味につ いて検討してみたい。朴澤家八代目を継いだ十四郎直春は、七代目 朴澤庄蔵が文政9年 (1826) 11月14日に藩へ提出した「朴澤庄藏養子願 書」 ${ }^{26)}$ によると、御作事方御職人組抜並御供大工阿部長左衛門の弟 で文政 9 年当時 26 歳、「十四郎義職目之儀者右左藏弟子二而細工稳古 仕罷在申者二御座候」とあるように七代目生蔵の弟子であった。ま た、前出の九代目左蔵の「朴澤左蔵履歴書」には「八代 朴澤十四郎 文政十一年ヨリ文久三年迄三拾五ヶ年奉勤仕候」とあり、さらに「朴

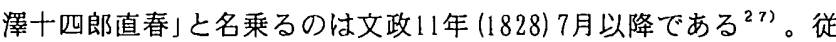
つて閃人改帳」の表紙に記される文政 11 年 (1828)8月の意味は、十 四郎が家督を継いだ時か或いはその直後のことと考えられる。

次に「門人改帳」に記載される人名に付された年月日について見て みたい。中鳴丈助から甚吉までは年月日が記されていないが、それ 以降は安政6年5月7日の幸吉と安政7年10月の松原幸八の順が入れ替 わっている以外、全て年月日順に記されている。年月日が記されな い阿部長左衛門について浊、文化4年 (1807) 7月28日付の「阿部左吉 跡式願書」 ${ }^{28}$ にに長左衛門儀 (中略) 組抜並御積横目大工加勢朴凙孫 太郎弟子二相附職目指圖稽古茂仕居候者二御座候」とあるので、文 化 4 年当時は十四郎直春の祖父孫太郎直壽の弟子であったことが知 


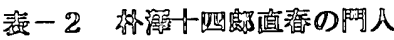

\begin{tabular}{|c|c|c|c|c|}
\hline \multirow{2}{*}{\multicolumn{5}{|c|}{ 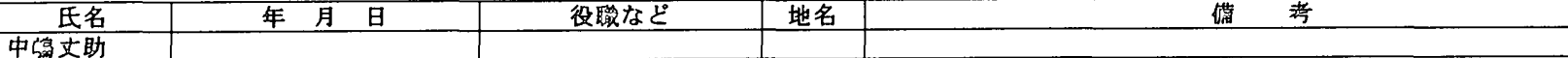 }} \\
\hline & & & & \\
\hline 㜔十郎 & & 篗大工 & & \\
\hline 阿部長左微門 & & & & 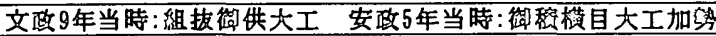 \\
\hline 菅野多利公 & & & & 天保 9 年当時:千田理兵衙组 \\
\hline \multicolumn{5}{|l|}{ 志贺忠治 } \\
\hline 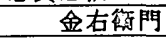 & & 御大工 & & \\
\hline 忠三郎 & & 御大工八平治弟 & & \\
\hline 甚古 & & & 一八関 & \\
\hline 外右衙門 & 天保 3 年 (1832)11月 & 嫼刺 & & \\
\hline 八十吉 & 天保 4年(1833)11月 & 徵大工 & & \\
\hline 和助 & 灭保 4 年 $(1833) 11$ 月 & 大工罯作化 & & \\
\hline 铨木鹳十郎 & 无保 4 年(1833)11月 & & 涌谷 & \\
\hline 竹中甚褯 & 天保 5 年(1834) 6 月 7日 & & 涌谷 & \\
\hline 志贺忠兵衡 & 天保 5 年 (1834) 6月22日 & & & 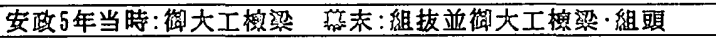 \\
\hline 山内酒三郎 & 无保 6 年 (1835) 8月 7日 & & & \\
\hline 鹿之丞 & 天保 6 年 (1835) 8月 7日 & 筧大工 & & \\
\hline 新十郎 & 灭保 6 年 (1835) 8月 7日 & 㬟大工 & & \\
\hline 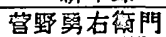 & 灭保 7 年 $(1836)$ 1月 5 日 & & & \\
\hline 譍治 & 灭㷛 7年(1836) 1月15日 & 箿小虽仮大工 & & \\
\hline 波川目左衙門 & 天保 7年 (1836) 1月15日 & & & 天保 9 年当時:千田理兵衡组 \\
\hline 金䓪 & 无㷛 7年(1836) 1月15日 & 篗大工喜十郎晜子 & & \\
\hline 的践門 & 天保 13 年 (1842)11月 & 復供大工 & & \\
\hline 暜八 & 无保13年(1842)11月 & 频門经 & & \\
\hline 菬平 & 天保14年(1843) 2月 & 篗大工 & & \\
\hline 今婺良吉 & 灭保14年(1843) 2月 & & & 天保9年当時:千田理兵筑组 \\
\hline 平治 & 天保14年(1843)11月 & 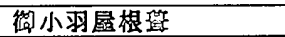 & & \\
\hline 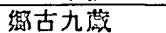 & 弘化 2年(1845) 8月 & 徨壁察 & & \\
\hline 飯㴶新五郎 & 弘化 2 年 (1845) 10月12日 & & & 表: 包山安兵衙组 \\
\hline 中村久之助 & 弘化 2年(1845) 10月12日 & & & \\
\hline 营野六平 & 弘化 3年 (1846) 1月19日 & & & 万延元年当時:千田理兵俈组 \\
\hline 飯野廦吉 & 弘化 3 年 $(1846)$ 2月 1日 & & & \\
\hline 山内彦五郎 & 弘化3年 (1846) 閏5月15日 & 甚三郎染 & & \\
\hline 演之助 & 弘化 4年(1847) 2月23日 & 裳大工 & & \\
\hline 今留治助 & 弘化 4年 (1847) 2月 24日 & & & 亲:組抜並御大工 \\
\hline 离古 & 弘化 4年 (1847) 5月 8日 & 微小虽仮大工 & & \\
\hline 紫涌進 & 弘化 4年 (1847) 6月 1日 & & 涌谷 & \\
\hline 阿部長太郎 & 湢永 4 年 (1851) 5 月 & & & 阿部長左衙門嫡子 \\
\hline 朴显七五郎 & 榴永 4 年 (1851) 5月 & & & 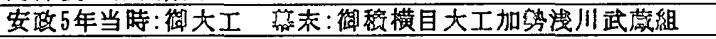 \\
\hline 藻右䱢門 & 泡永 4年(1851) 6 月 & & & \\
\hline 今野市郎兵衙 & 泡永 4年(1851) 6月 & & & \\
\hline 石田平三郎 & 落永 4 年 (1851)10月18日 & & & \\
\hline 坂野久兵衡 & 清永 5年(1852) 2月 1日 & & & \\
\hline 後濷定古 & 薄永 5 年 $(1852)$ 2月13日 & & & 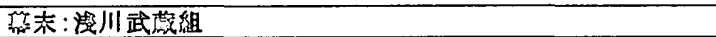 \\
\hline 久治 & 䆗永 5 年 $(1852)$ 2月 13 日 & 时大工 & & \\
\hline 阿部幸四郎 & 客永 5年 (1852)10月27日 & & & \\
\hline 六之助 & 浬永 6 年 (1853)11月 23 日 & 篑小属仮大工 & & \\
\hline 䞒疗要三郎 & 哆永 7年(1854) 3月 20 日 & & & \\
\hline 湆之助 & 㽞永 7年 (1854)10月15日 & 略町太郎保町大工 & & \\
\hline 踰木伊八郎 & 湆永 7年(1854)11月16日 & & & 保表：阿部幸太夫组 \\
\hline 竹中平治 & 安政 2年(1855) 7月11日 & & & \\
\hline 茂右衡門 & 安政 2 年 (1855)10月 5 日 & 微刺够大工 & & \\
\hline 大澨 & 安政 2年(1855)10月5日 & 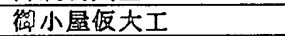 & & \\
\hline 椱五郎 & 安政 2 年(1855)10月 5日 & 町大工 & & \\
\hline 松治郎 & 安政 2年(1855)10月 5日 & 町大工 & & \\
\hline 兵三郎 & 安酷 3年(1856) 9月 5日 & 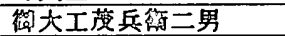 & & \\
\hline 言藍 & 安政 5年(1858) 6月 8日 & 得大I & & \\
\hline 幸吉 & 安政 6年(1859) 5月 7日 & 得大工 & & \\
\hline 松原幸八 & 安政 5 年 (1858)10月 & & & 表:阿部幸太夫甜 \\
\hline 松原助五郎 & 安政 7年(1860) 2月 7日 & & & \\
\hline
\end{tabular}

られる。この他の年月日が記されない者については不詳であるが、 年月日が記される者についてみると、役職の上位下位や或いは瞕種 の違いと閒人改帳」における記載順序との間には関係が認められな い。従って門人改帳」に記される年月日は十四郎直春の門下となっ た年月日であり、これが記されない者は十四郎直春の先代或いは先 々代の時に朴凙氏の門下となった者と推されよう。つまり「門人改 帳」は入門の順に氏名を記したと考えられるのである。

記された地名についても考えてみよう。閃人改帳」に記載される 人名の内、1名には「一ノ関」、3名には「涌谷」と付記される。藩政期 の一関には田村氏を領主とする仙台藩の支藩である一関藩が置かれ、
涌谷には仙台藩主伊達家の一門である伊達安芸の要害が置かれてい $た^{291}$ 。「門人改帳」に涌谷の地名と共に記される鈴木勘十郎につい ては、その素性を考える上で手掛かりとなる史料が若千残されてい る。即ち、寛文 13 年 (1673) の伊達安芸宗重廟槽札に「奥州遠田郡涌 谷住棲梁鈴木氏実冒」ととうりやう鈴木長右衛門小、元禄10年 (1697) の妙見宮拝殿矢板及び槙札にそれぞれ「奥州遠田郡涌谷住樌梁鈴木 氏直昌」「楎梁鈴木勘十郎直昌」、正徳元年 (1711)の伊達安芸宗重廟 屋根替栖札に「奥州遠田郡涌谷住楎梁鈴木長右衛門直昌四代」と記さ れているのである ${ }^{30)}$ 。これらを総合すると、涌谷には代々の通称 を長右衛門又は勘十郎とする鈴木姓の槽梁家が存在し、この家系は 
正徳年中には既に四代を数えていたことになる。閃人改帳」に記さ れる涌谷の鈴木勘十郎は、地名、姓、通称から鑑みてこの棟梁家の 子孫或いは一族の一人と考えられよう。従って、門人改帳」に記さ れるけノ関」涌谷」の地名は、それぞれ支藩或いは要害拝領者の支 配下にあった大工、或いは居住地を示していると思われる。

さて、十四郎直春の門人の役職には御供大工・御大工・御小屋仮 大工・町大工があり、各階層に跨っていたことが知られる。また瞕 種も、大工の他に畳刺・御小羽屋根苜・御壁垐 - 御刺物大工と多岐 に渡る。門人達が所属していた大工組について、入門当時の所属組 が知られるのは現在のところ今野良吉 (棟梁千田理兵衛組)のみであ る ${ }^{6)}$ が、幕末期 ${ }^{31}$ には飯野新五郎は棟梁龟山安兵衛組、管野六平 性棟梁山内甚太夫組、朴澤七五郎と後藤定吉は棟梁浅川武蔵組、鈴 木伊八郎と松原幸八は棟梁阿部幸太夫組にそれぞれ属している。つ まり門人達は所属組の別なく入門していたことが知られる。

この様に朴澤家が一門を形成するようになった時期は、前に触れ たように文化4年 (1807)には六代目孫太郎直壽が阿部長左衛門を弟 子としているので、遅くともそれ以前のことと考えられよう。

\section{4. 仙台䟧における㮩古人制度}

仙台藩において四天王寺流の継承がどの様になされていたのかを 筧うことが出来る史料に「御積横目大工加勢阿部韦左衛門. 御路地佐 久間慶蔵願畫」 ${ }^{32)}$ と呼ばれるものがある。これは控えであり、同じ 内容のものが2通残されている。1通は前半と後半が欠如しており、 もう1通も前半が欠如しているが、相互を照会することによってほ ぼ内容が把握できる(巻末の[史料 3 ] 参照)。奥付活壬八月廿九日」 で年号は記されていないが、内容から朴澤家八代目十四郎直春の死 後間もなく記されたものであるので、これは文久2年 (1862) 閏8月29 日であることが知られる。史料内容の概略は以下のようなものであ る。安政5年 (1858) に御積横目大工の千田左五郎と亀山小太郎並び に朴澤十四郎直春の三人に稽古人が付けられた。直春の稽古人は御 大工棟梁志賀忠兵衛の嫡子生三郎、御大工朴澤七五郎、御積横目大 工加勢阿部長左衛門の嫡子長太郎であった。この三人の稽古人の内、 阿部長太郎は文久2年 (1862) 正月に病死したが、志賀生三郎と朴澤 七五郎は直春から木匠道の皆伝を受けた。ところが直春は文久 2 年 (1862) 8月に病死してしまった。直春の死後、朴澤家に伝来する多 くの書巻絵図等が粉乱することを防ぐため、千田左五郎と亀山小太 郎がこれらに印符をした。志賀左三郎と朴澤七五郎は直春から木匠 道の皆伝を受けたものの、未だ大造 (大作)の書巻絵図等の筆写迄は 済んでいなかったので、両名はこれらを筆写したい旨を阿部長左衛 門等に申し出た。これを受けて幼少の朴澤家当主に代わって親類で ある阿部長左衛門等が筆写許可を願い出た、というものである。

先ず、直春に付けられた三人の䄸古人について見てみたい。前出 の「門人改帳」には志賀生三郎の名は記されていないが、朴澤七五郎 と阿部長太郎の両人は直春の稽古人となる以前の嘉氷 4 年 (1851) 5 月 には既に直春の門人になっている。従って䄸古人と門人とは異なる ものであったことが知られ、前者は「従御上被相附」とあることから 藩命による公的な木匠道の継承候補者であり、これに対して後者は いわば私的な弟子と解されよう。これに関連して仙台藩の御作事方 棟梁を勤めた米野善吉安代の墓誌 ${ }^{33)}$ には「安代者番匠也低命属朴澤 直好而得四天王寺流神社佛殿七堂伽藍準縄城郭宮室楼櫓諸器規矩曲

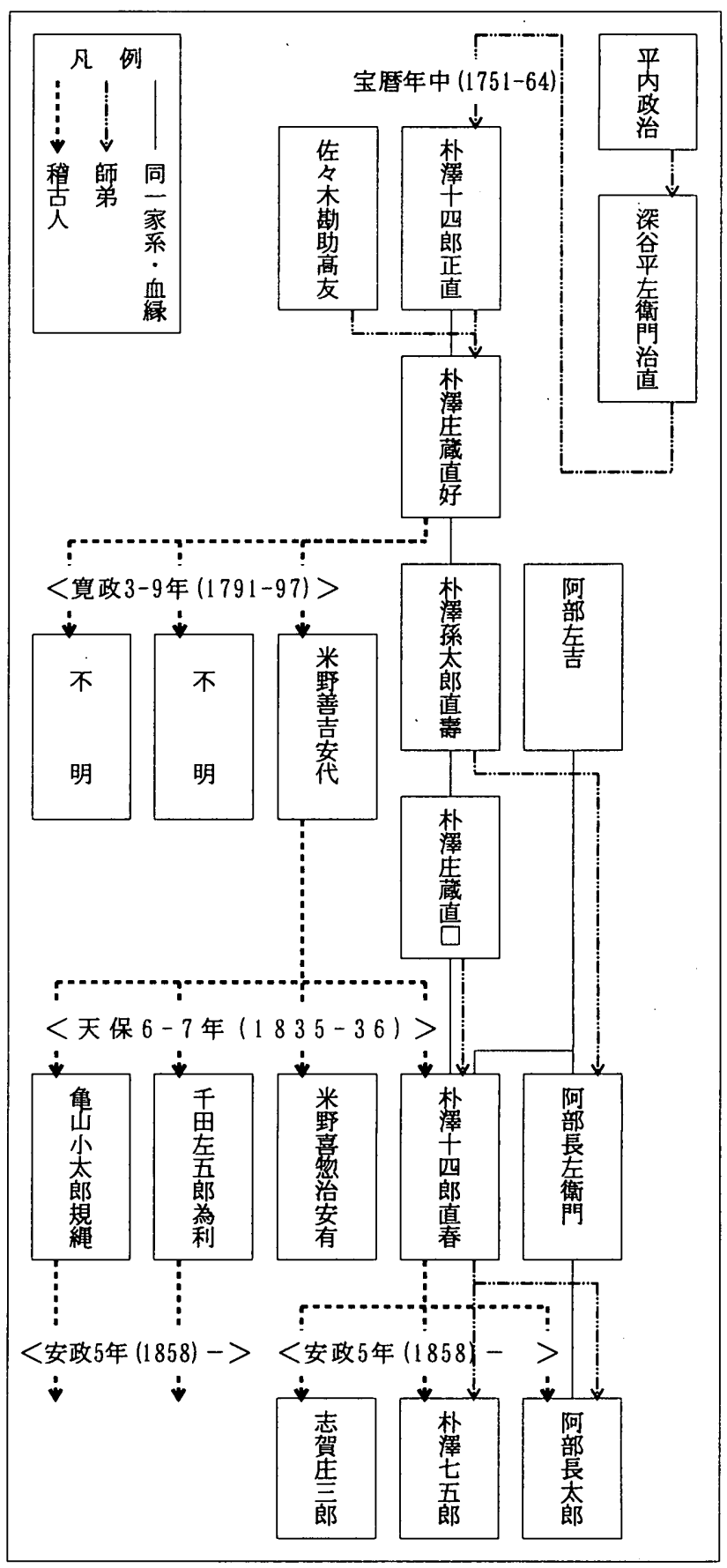

図-2 仙台潘における四天王寺流の系譄

尺傳方神道祭禮行事極秘矣 (中略) 天保六年蒙命附属番匠朴澤十四郎 直春米野喜涊治安有千田左五郎為利龟山小太郎規縄四人為木匠職糐 古人天保七年所傳之極秘悉傳日人官賜金千疋賞其労 (後略)」とあり、 天保6年 (1835)に米野善吉に付けられた四名の嵇古人もやはり「命」 によるものであった。また米野善吉は「命」によって朴澤直好に属し て四天王寺流の極秘を得たとあるが、朴澤直好の墓碑には「(前略) (寛政)三年辛亥蒙命属番匠三人蓋於我邦内建工家師弟者起干此矣 (後略)」とあることから、「命」によって直好に付いた三人の番匠の 内の一人が米野善吉であったと推されると同時に、この「命」による 嵇古人の濫䚚は寛政 3 年 (1791) であったことが知られるのである (図 -2)。なお、㮁古人の存在は御作事方御職人組抜御大工で永々諸色 彫刻唐彩色兼職平榮三郎の「勤書 ${ }^{34)}$ からも知られる。即ち「同 (天 
(保)十年所々御修復方相勤候処批者方江従 上諸色彫刻唐彩色之嵇古 人六人弟子二被相附難有仕合奉存候」とあり、木匠職以外の諸色彫 刻唐彩色を専門とする工匠にも嵇古人の制度が存在しており、藩命 によって糐古人を付けられることは名誉なことであった。

さて、朴澤七五郎と阿部長太郎は直春の門人になって7〜8年経過 した後に槢古人となっており、前者は「御大工」と記されていること からも既に一人前の工匠であったと推される。また、米野安代の稽 古人となった朴澤直春は前述のように朴澤家七代庄蔵の養子になる 26歳頃まで生蔵の弟子として細工秮古をしており、揹古人になる以 前から既に門人を採っていた。これらのことから嵇古人は或る程度 の技術的水準に達した藩工匠の中から選ばれていたと考えられ、こ のことは、寛政3年 (1791)に朴澤直好に付けられた3人の稽古人は同 9年 (1797)に、天保6年 $(1835)$ に米野安代に付けられた4人の穕古人 は翌年に、安政 5 年 (1858)に朴澤直春に付けられた2人の稽古人は遅 くとも文久 2 年 (1862) 8月以前に、というように比較的短期間の内に 皆伝されていることからも首肯できよう。現在のところ、穕古人達 が如何なる研銘を積んだかという点について全貌を詳細に知ること は出来ない。しかしながら朴澤直春の糐古人達の例を見ると、師家 に伝わる書巻絵図類の筆写がその重要な任務の一つであったことは 知られる。これらの書巻絵図類が木匠道継承にあたって如何に重要 視されていたかは、朴澤直春の死後直ちに同家に伝来する多くの書 巻絵図等に印符され、しかも直春から皆伝を受けた稳古人は勿論の こと、朴澤家の親類でさえも勝手にこれを開符する事が出来なかつ たことなどから䇲える。これらの維持管理は単に一工匠家のみによ ってではなく、藩によっても厳格に行われていた。これら書巻絵図 類の筆写は嵇古人などの限られた者にのみ許されていたのである。

结

本編では、仙台藩の代表的な工匠家の一つであった朴澤家に遗さ れた史料を基にして、江戸幕府 (中央) の建築技術である四天王寺流 が同藩 (地方)へ伝播していく経緯とその後の藩内での流派継承の在 り方などについて明らかにした。以下にその要約を示す。

1) 仙台藩では、藩草創期以来元禄期 (1688-1704) 頃まで京都や紀 州・泉州などの上方から建築文化や技術を積極的に導入していたが、 宝暦期 (1751-64)に至り江戸のもの、即ち四天王寺流の導入を図っ た。四天王寺流の根本木割書である「匠明」が現在のような形に大成 されたのが京保期 (1716-36) であることを併せ鑑み、同流は元禄期 以降に確立されて遅くとも宝攵期には当時の建築界を代表する流派 の一つとして諸藩にも認識されるようになったと考えられる。

2 ）仙台藩への四天王寺流導入にあたり、中心的な役割を累たした のは同藩の御大工楎梁職にあった朴澤十四郎正直であった。正直は 藩命によって江戸に登り、幕府大栖梁平内政治の門弟樑谷平左衛門 治直より宝攵年中 (1751-64)に四天王寺流の皆伝を受けた。正直は 四天王寺流を相伝した後、「御足軽御小人組抜並刀御免」という工匠 としてはかなり高い格式を与えられた。

3）仙台藩に於ける木匠道継承の在り方の一つとして、幕末期に朴 澤十四郎直春が総勢59人もの門人を擁した例に見られるように、家 格・役職・大工租・職種などを問わず広く藩内から弟子を採る方法 があった。また、これとは別に技術的に或る程度の水準に達した藩 工匠の中から稽古人と呼ばれる木匠道継承の候補者を養成する制度
があった。門人がいわば私的な弟子と考えられるのに対して、揹古 人は蕃命によって定められた公的なものであった。この揹古人の濫 解は、寛政3年 (1791) に藩命によって朴澤庄蔵直好に3人の番匠が付 けられた時である。

4) 木匠道の継承に於いて、朴澤家に伝来した建築技術書類は重要 な意味を持っていた。これらの筆写は嵇古人などの限られた者にの み許されていた。また、朴澤家に伝来したそれらの建築技術書類の 維持・管理は単に朴澤家のみならず、藩によっても厳格になされて いた。

\section{良括}

史料の閲覧・収集に際して仙台市博物館の御協力を得た。ここに 記して謝意を表したい。

\section{茫}

1) 例えば、加賀潘においては建仁寺流や四天王寺流を唱える工匠が 存在したことが知られている。

2)内藤昌「『匠明』祖本：『諸記集』について一流派成立の一考察」 (日本建築学会大会学術講演梗概集, 昭和 50 年) や中川武「「匠明] と「諸記集」について」(同前, 昭和53年)などの論考に見られるよ うに、四天王寺流の根本的な木割書である任明」の成立過程やそ の時期についても諸説があった。「匠明」5巻の内、「社記集」に関し ては永井康雄·飯潤康一「「匠明·社記集」の成立過程について」(日 本建築学会計画系論文集，第487号，1996年) で明らかにしている。 また、四天王寺流の平内家や建仁寺流の甲良家の家譜及び業績に ついては、田邀泰「江戸幕府作事方職制に就て」(建築雑誌第598号， 昭和 10 年)，田邀泰[江吉幕府大槙梁甲良氏に就て」(建築雑誌第 609 号、昭和 11 年)に詳しく、近年では内藤昌门近世大工の美学 環 境倫理としての日本古典建築学」(中央公論社, 1997年)などがあ る。加賀潘における建仁寺流大工については，田中徳栄「加賀藩大 工の研究一主として建仁寺流大工山上家について一」昭和55年 度科学研究費補助金奖励研究 (B) 報告書)に詳しい。

3)「朴沢家資料」, 仙台市博物館藏。

4)「朴沢家資料」では，次のものを用いた。(1)「御名乗ノ事」寛保 2 年 (1742)，(2)「御名乗ノ事」宝暦13年 (1763)，(3)「朴澤庄蔵䅰居願」寛 政9年 (1797)，(4)「阿部左吉跡式願書」文化4年 (1807)，(5)「朴澤左蔵 美子願書」文政9年 (1826)，(6)「御名乗ノ事」文政11年 (1828)，(7)「朴 澤十四郎養子除キ願書」安政5年 (1858)，(8)「朴澤十四郎一季書上」 万延2年 (1861)，(9)「朴澤十四郎養子除丰願書」文久元年 (1861)， (10「御積横目大工加勢阿部長左衛門·御路地佐久間慶蔵願書」文久 2年 (1862)，(11)「朴澤左蔵改名願書」文久3年 (1863)，(12)御名乗/事」 文久3年 (1863)。この他に，13「朴凙左蔵直好先生の墓碑」(棠城縣 史17 (金石志)，昭和 31 年，宮城縣」)を参考にした。

5)「仙蓋市史8 資料篇1」(仙蜜市役所, 昭和28年) 所収。

6) 小山祐司「江戸時代末期における仙台藩御大工と御大工大工組に ついてー千田家文書を中心として一」(褁北工業大学紀要 I :理工 学編第13号, 1993年)。

7)例えば，六代目孫太郎が「組抜並」（註4)の(4)），七代目左蔵が「組 抜並」（同(5)，八代目十四郎が「御足軽御小人組拔並」（同(7)(9) 九代目庄蔵が組抜並」(同(11) などである。

8) 註6) 論文によると、幕末期の仙台藩には5 組の大工組が存在し、各 組にはそれぞれ45人前後の御大工が属していた。

9)「仙蜜昔話 電狸翁夜話 (復刻版)」(小西利兵衛螎集, 今野印刷株式 会社, 平成2年)。

10)例えば, 註4)の(5)の差出人である朴沢左蔵·阿部長右衛門·朴沢養 吉·佐藤太右衛門の肩書きは、それぞれ「組抜並御絵圖方主立」(本 文中では「組抜並御大工御絵圖方主立」とある・「御作事方御職人 組抜御供大工」·右左蔵親類 御大工脇棈梁仮役」·右長右衛門親 類 御籍元足輕」である。

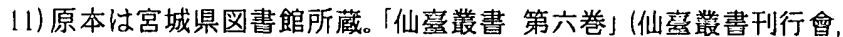
大正13年) 所收。 
12)この項目には21人の氏名と進退·職名等が記されており、この中 に「御作事方職人組抜御大工」同 (御作事方職人組拔) 御張付」と 記される者が含まれている。この他、作事方に関係する項目には 「御作事方職人」御作事方職人大工」がある。前者は「人数四百参 拾七人」と個人名を記さない。後者には10人の個人名とそれぞれ の知行高を記しているが、何れの人名にも「組抜並」などの局書は 記されていない。

13）御郡奉行支配/御大官/在郷御番外/同御給主/同御足軽/内組頭 㦿頭有/御足軽御小人組拔並/龍ヶ崎御足軽/内組頭有」とある。

14) 註4) O(13).

15) 宮城県図書館蔵。

16) 太田博太郎監修·伊藤要太郎解説「匠明·匠明五巻考」(鹿島出版会, 昭和 46 年) には平内家第十一代目但馬政徳が慶応 4 年 (1868)に記 した平内家由緒書の写しが載せられている。これによると三代目 大隅政治は天和 3 年 (1683) 跡式·享保元年 (1716) 病死、四代目七郎 左工門信直は同年跡式·同 12 年 (1727) 病死, 五代目長門政長㹥同年 跡式·安永3年 (1774) 病死しているので, 朴澤家が四天王寺流を皆 伝された宝暦年中 (1751-64)の平内家当主は政長ということにな る。しかしながら、東京大学所蔵の平内家旧蔵書の中には「元文四 年 (1739) 戊未四月吉日武州江戸四天王寺流本家之巧匠平内政治 門弟深谷平太夫治直圖定傳者也」という奥書を有するものが何点 も存在している(例えば「社類建地割」佛殿建地割」など)。従って 朴澤十四郎は平内政治の門弟であった深谷治直の門弟になって 皆伝も同人から受けたのであったが、「仙台棟梁譄」では朴澤十四 郎は平内政治の門弟になり皆伝法深谷治直から受けたと解釈し たものと考えられる。

17)「朴沢家資料」，仙台市博物館蔵。年未詳12月。朴澤十四郎が勤仕し た主な普請場所、藩主への御目見、俨美、御誉について書き上げた ものの控え。

18)「徳川實紀了宝暦元年 (1751)6月29日条。

19)庄内藩の大工棟梁職を勤めた小林家には慶安4年 (1651)の奥書を 有する匠明・社記集」の写本が伝来した。埌内藩は慶安度江戸城 西之丸の御手伝普請を行っており、小林家旧蔵史料の中にもこれ に関するものが残されていることなどから、同家はこの普請に従 事する中で[匠明・社記集」を筆写する機会を得たものと考元られ る。言主2) 拙稿参照。

20) 横山秀哉「伊達家御大工梅村日向考」(日本建築学会研究報告, 第 42 号，昭和33年6月)。

21) 現社殿は四代藩主伊達網村が元禄8年 (1695)に着工し、五代藩主 伊達吉村の宝永元年 (1704)に落成したものである。

22)「仙台棟梁譜」によると松原助兵衛は本名を重成といい、「伊達治 家記録」元禄8年 (1695) 2月条からは踑踢ヶ岡釈迦堂 (仙台市宮城 野区) 建立時の大工棟梁であったことが知られる。

23) 谷直樹「中井家大工支配の研究」(思文閣出版, 平成 4 年)に元禄 5 年 (1692) 当時の中井家配下棟梁衆が一覧表として線められている。 これに記される4人の頭棟梁の中に法隆寺大工出身として藤本丹 波の名が見られる。

24) 註16) 伊藤要太郎著書、及び註2) 拙稿。

25)「朴沢家資料」，仙台市博物館蔵。

26) 註4)の(5)。

27)註4) 0(6)。目付は「文政十一戊子年七月吉日」である。

28)註4）0(4)。文化4年6月6日に御作事方御職人組抜御大工阿部左吉 が死去し，その跡式 (御切米四両御扶持方五人分) を嫡子御小屋仮 大工長右衛門に下置加孔るう，御第元足軽佐藤兵左衛門と組抜 並御積横目大工加勢朴澤孫太郎が連名で差し出したものの控え。

29) 仙台藩の上層藩士である門閾は，格式によって一門・一家·準一家 ・一族·宿老·着座・太刀上·召出に分けられていた。この中には城 に準じる軍事上の重要施設であり、その補修に際しては幕府への 届け出が必要とされた要害を藩主から拝領した者もあった。

30)「涌谷町史小 (昭和 40 年) 所収。

31)「大年寺造営扣」斎藤報恩会藏。

32)註4)の(10。

33)「米野善吉安代墓誌」(宮城縣史 17 (金石志)，宮城縣, 昭和 31 年) 所 収。

34) 原本は斎藤報恩会蔵。なお、この写本は宮城県図書館に所蔵され ている。

\section{[史料 1] 朴澤庄蔵直好の墓碑（部分）}

(「宮城縣史 17 (金石志)」(宮城縣, 昭和 31 年) 所收) 朴澤氏俗名庄藏藤原直好自父世壽禄次干下士工匠家也少而受業於父 十四郎其師深谷平左衛門治通先師四天王寺流江府平内政治也後以同 流佐々木勘助為師 (中略) 於神社佛殿七堂伽藍準縄城郭宮室楼橹諸器 規矩矣 (中略) 神學漢學兵學釈教曲藝所關工家問其梗概編為造営之一 助也 (中略) 寛政元年已酉温崇木匠枢要諸籍考訂工家流徒著述数百巻 書以奉進焉三年辛亥蒙命属番匠三人蓋於我邦内建工家師弟者起干此 矣 (後略)

\section{［史料 2］朴澤庄葴履歴書（部分）}

(前略)

一四代 朴澤十四郎

享保元年ヨリ眑棟梁及御積り職相勤御切米渐々御加增被成下小判 四両二三人分ノ高二被下置享保十三年苗字御免二被成下同年御大 工棟梁被仰付御役料御切米小判式両三歩御扶持方三人分被下置進 退御切米取合セ小判六耐三歩御扶持方六人分ノ高二被下置寛保元 年五月御役料ノ御扶持方三人分御切米式両三歩御加增卜シテ被下 置宝暦十二年御足軽御小人組抜並刀御免二被成下享保元年ヨリ明 和二年迄五拾ヶ年奉勤仕候

一木匠道八木匠家大祖神 神代手置帆負 彦狭知ノ二神二候処漸々 傳来相成武州江戸四天王寺流祖家公儀棟梁平内政治門弟同棟梁梁 谷平左卫門治直殿ヨリ相傳申受候

一唯一神道祭禮行事式八仙臺藩國學士佐藤左内殿へ入門仕神社造営 鳥井一社社之由来祭禮行事式等其職二関シ候分洩ナク相傳申受候 得共御許可之儀八佐藤左内自身二取扱兼候二付京都ヨリ表向相傳 申受候事八過分 奴入費相脚り候二付䙾保年中京都野々宮様御家司 津川隼人正殿へ左内殿ヨリ御頼三登都野々宮様へ御披露相成御家 司人ヨリ手続习経テ御許可状被下置候（中略）

一天文諸器/儀八藤彦大郎殿ヨリ天象測器之曲尺合其外旧尺或八日 月星辰之運行赤道南北両極之配等傳法相済候

一兵學八甲州信玄流飯田喜市殿ヨリ陣屋備郭天守殿主櫓等之縄張建 方等其外器物之寸法等相傳申受候

一茶道八石州流座教囲寸法等清水道简左殿ヨリ相傳申受候

一禮方八和田平助殿ヨリ小笠原流産屋并婚禮御寔子黒棚器物等之据 方相傳申受候
一五代
朴澤左藏

御大工棟梁直々被仰候御役料御切米金三歩取合七金六両三歩御扶 持方六人分二被成下寛政三年九月御役料御切米金三歩御加増二被 下置取合セ御切米金六両三歩御扶持方六人分ノ高二永代禄卜シテ 被下置此直シ高六貫五百六拾壹文明和二年ヨリ寛政三年迄棟梁職 式拾七ヶ年奉勤仕候 （後略）

[史料 3 ] 御積横目大工加勢阿部長左㫦門·御路地佐久間序藏願書 （破損）中御積横目大工千田左五郎同龟山小太郎右三人之方江安政 五年何月中木匠道䄸古人従御上被相附候処右十四郎手前江御大工棟 梁志賀忠兵衛嫡子同苗左三郎并御大工朴澤七五郎御積横目大工加勢 阿部長左衛門嫡子同苗長太郎右三人被相附稽古罷在候処右長太郎義 當正月病死仕候義二在之右左三郎七五郎等式人者開傳相済候通二御 座候処右十四郎當八月中病死仕候二付右木匠道朴澤家傳来に付粉乱 不仕様拙者共立億夫々取始末仕置候処其後右左五郎小太郎等被相越 木匠道傳来数多之書巻等江印符仕差置候処朴澤家之始末迠他家之者 被相越右様印符等仕候も不相分事 $\square$ 奉存候得とも夫 $\square$ 二仕置候後二 御座候然二右糐古人左三郎七五郎等開傳者相済居候得共木匠道之書 巻絵圖等大造之儀二在之写方站八行届兼㖪在候間写方仕度段拙者共 手前江申聞無余儀訳二有之候併前文之通左五郎等印符付指置候儀二 而拙者共とても勝手開符可仕様無御座候間御指圖之上開符仕右左三 郎等江相渡写方為被仕度奉存候間早速御吟味御指圖被成下度右口次 郎當時幼少二而罷在拙者共儀依親類此段相達申候以上

$\begin{array}{ll}\text { （文久2年） } & \text { 御積横目大工加勢 } \\ \text { 壬八月廿九日 } & \text { 阿部長左衛門 } \\ & \text { 御路地 }\end{array}$

佐久間慶蔵 